\title{
Philosophies of interreligious dialogue
}

\author{
Practice in search of theory
}

$\mathrm{n}$ this article, I discuss how insights from Martin Buber's and Emmanuel Levinas' philosophies of dialogue have enlightened my own experience of interfaith dialogue in Norway. Central perspectives here are Buber's notion of 'the realm of the between' and Levinas' emphasis on asymmetry and vulnerability. Some other philosophers' reasonings about dialogue are also considered, from the overall perspective of 'practice in search of theory'. In connection with a distinction between different types of dialogue ('spiritual' and 'necessary'), the difference between government initiated 'dialogue' and initiatives originating from the faith communities (i.e., civil society) are discussed. The last part of the article analyses the notion of '(mutual) change' which is often brought forward when discussing the aims of interfaith dialogue. In this connection, religious education in school is also considered as a possible arena for dialogue-and 'change'.

In late modern philosophies of interreligious dialogue, Martin Buber and Emmanuel Levinas have often figured as important points of reference (e.g. Atterton et al. 2004, Illman 2006). Other points of reference have been the pedagogical and social philosophies of Paolo Freire and Jürgen Habermas. None of these-moral, social, pedagogical-philosophers have had interreligious relations as their primary focus in their reflections on dialogue. But their philosophies of dialogue and communicative action have caught the interest of people who have been involved in and/or tried to understand the dynamics of interreligious dialogues. In my case, engagement in philosophies of dialogue has evolved as practice in search of theory, but also as a search for a theory that may guide future action in the field of interreligious dialogue.

\section{Spiritual and necessary dialogues}

My first reflections on Buber and Levinas can be found in my book Religionsdialog på norsk (Interreligious dialogue in Norwegian) which was published in 1996 (Leirvik 1996: 152-6). At that point, I was in a period of transition from church-based involvement in interfaith dialogue ${ }^{1}$ to academic work in the field of interreligious studies. ${ }^{2}$ In the book referred to above, I introduced a distinction between 'spiritual' and 'necessary' dialogues (Leirvik 1996: 157-80). Whereas spiritual dialogues are based on personal motivation and are guided by an expectation of being enriched by other spiritual traditions (a typical example would be Christians and Buddhists meditating together), necessary dialogues are driven by a felt socio-political need to prevent or reduce religionrelated conflict in society, by fostering peaceful interaction between representatives of different religious groups.

In what follows, I will distinguish between philosophies of spiritual and necessary dialogues respectively. I will also deal with ethical and religious dialogue in school as a category in itself, under the label of 'dialogue didactics'.

As for the notion of necessary dialogue, I shall be referring mainly to interfaith dialogues in civil society, initiated by the faith communities. In the Norwegian context, both the bilateral Contact Group between the Church of Norway and the Islamic Council of

1 I made my first experiences in Christian-Muslim dialogue when working as a Lutheran pastor in an inner city congregation in Oslo (from the late 1980s) and worked subsequently full time with interfaith dialogue in the church-related Emmaus Centre for Dialogue and Spirituality (until 1996).

2 At the Faculty of Theology, University of Oslo (from 1996). 
Norway (established in 1993) ${ }^{3}$ and the country's multilateral interfaith council (The Council for Religious and Life Stance Communities, established in 1996) 4 have come about on the initiative of the faith communities, with no involvement from the political authorities. It should be noted, however, that in the European context the term 'dialogue' is increasingly used as a heading for government-initiated communication with the minority communities, especially the Muslims (Amir-Moazami 2010). ${ }^{5}$ In this case, one would expect 'dialogue' to be more oriented towards disciplinary measures, in line with Foucault's concept of governmentalization (Lemke 2002) and (more recently) security concerns. ${ }^{6}$

In civil society dialogues as well, there are imbalances in power. In theorizing about interreligious dialogue, it is still necessary to distinguish between government-initiated 'dialogues' and civil society initiatives-or from a wider perspective, between dialogue at the levels of state and society respectively. In my following discussion of dialogue (be it spiritual or necessary), my point of reference will be communication between the faith communities in civil society, not state initiatives.

\section{Philosophies of spiritual dialogue}

My first experiences with joint meetings between church and mosque in Oslo took place long before the political authorities had established any form of 'dialogue' with the minorities. It also happened before the increasing politicization of Christian-Muslim relations after the fall of Communism and the

exty Norwegian example would be a newspaper article from 2005 by the then Minister of Municipal and Regional Affairs Erna Solberg, with the heading 'Dialogue with religious milieus' ('Dialog med religiøse miljøer', Vart Land 12.7.2005). The article should probably be read in light of an interview with Solberg two years before, in which she (after a conversation with the British Minister of Inclusion) encouraged Norwegian Muslims to modernize their Islam ('Solberg utfordrer norske muslimer', Aftenposten 4.11.2003).

6 A Norwegian example of how the notion 'dialogue' is embedded in discourses of securitization can be found in the Ministry of Justice and the Police's plan from 2010 'to prevent radicalization and violent extremism' (Justis- og politidepartementet: 'Felles trygghet - felles ansvar. Handlingsplan for å forebygge radikalisering og voldelig ekstremisme', pp. 24, 32.) first Gulf War. Two of these memorable first events of Christian-Muslim dialogue took place in 1988-9 and was (typically of those innocent times?) focused on the spiritual theme of prayer (Leirvik 1990: 9-18).

Although my main interest as a dialogue activist has been Christian-Muslim dialogue, my work with the Emmaus Centre for Dialogue and Spirituality in the mid-1990s brought me also into conversation with alternative spiritualities. It was in this connection that the philosophies of Buber and Levinas first caught my attention and in the book from 1996 mentioned above I engaged both of them in my discussion of the relation between Self and Other in New Age spirituality.

In the same year, Paul Heelas's well-known interpretation of New Age spirituality as 'self religion' was published under the title New Age Movement. The Celebration of the Self and the Sacralization of Modernity (Heelas 1996). In a critical comment to what I saw as a one-sided focus on the Self and a neglect of the relational element of spirituality in many New Age movements, I invoked Buber's remark in I and Thou:
Spirit is not in the I, but between I and Thou. It is not like the blood that circulates in you, but like the air in which you breathe. Man lives in the spirit, if he is able to respond to his Thou. $\mathrm{He}$ is able to, if he enters into relation with his whole being. Only in virtue of his power to enter into relation is he able to live in the spirit. (Buber 1987: $57 \mathrm{f}$.)

This was the context for my first encounter with $\mathrm{Bu}$ ber's notion of the space between, which became later a guiding notion also for my reflections on Christian-Muslim dialogue (Leirvik 2006: chs 10 and 26; Illman 2006: 27 f.).

Buber's notion of the spirit between was not only formulated as an interpretation of the dynamics of spiritual dialogue, but also as a cultural critique against any kind of self-centred philosophy. Buber is, however, nuanced in his approach to the question of selfhood and relatedness. Part of the context for Buber's reflections on human relationships in I and Thou was Carl Gustav Jung's psychological (and archetypical) perception of the Self as distinct from the Ego. In tune with Jung's concern for personal wholeness, Buber valued mystical and psychodynamic practices aimed at 'the soul's becoming a unity' (Buber 1987: 112), but only as a preparation for I's authentic encounter with Thou. In this connection, Buber warns 
also against reducing the notion of dialogue to an internal conversation between I and the (Jungian) Self:

All modern attempts to interpret this primal reality of dialogue as a relation of the $I$ to the Self, or the like - as an event that is contained with the self-sufficient interior life of man - are futile: they take their place in the abysmal history of destruction of reality (Buber 1987: 111).

These are strong words and the radical nature of $\mathrm{Bu}$ ber's cultural critique as expressed in the above quote can hardly be overlooked. From a metaphysical perspective, Buber was explicitly critical of Jung's insistence that 'the divine action arises from one's own self' (Buber 1988: 133). Instead, Buber located also the spiritual (or divine) in what he would later term 'the realm of between' (Buber 2002: 243). As he explains in I and Thou: 'The extended lines of relations meet in the eternal Thou' (Buber 1987: $57 \mathrm{f}$.).

For me as a Christian theologian, Buber's reflections on the relational nature of human existence and divine reality made deep sense and shed new light on my sometimes frustrated conversations with representatives of New Age spiritualities.

In 1996, I supplemented my Buberian critique of self-centred spirituality with insights borrowed from Emmanuel Levinas, whose philosophy I at that point only knew through the Norwegian edition of Humanisme de l'autre homme (Levinas 1993) and ongoing research by a friend who applied Levinasian insights on the practice of massage - as a 'dialogue without words' (Grødum 1999).

More clearly than Buber, Levinas emphasized the difference between I and Thou-as epitomized by Levinas' substitution of the term 'Thou' for 'the Other'. Whereas Buber's reasoning on the encounter between I and Thou is marked by the intimate language of love, Levinas meditation on the Other's face is focused on vulnerability and responsibility. In an interview with Levinas made by Asbjørn Aarnes (a main proponent of Levinas' thought in Norway) and added to the Norwegian edition of Humanisme de l'autre homme, Levinas says: 'The wonderful thing about the face is that is says, it says: need, vulnerability, it asks, begs $m e$ for help, it makes me responsible' (Levinas 1993: 214, my translation). This is also how Levinas sees the way to God: 'God, the god, it's long way there, a road that goes via the Other. Loving God is Loving the Other. .' (Levinas 1993: 215, my translation).

With such insights, Levinas builds a firm bridge from spirituality to ethics and thus also to the necessity of dialogue. In a later edition of Religionsdialog på norsk (Leirvik 2001) I returned to Buber and Levinas in a meditation entitled 'God is greater', this time not in relation to alternative spirituality but to religious fundamentalism (Leirvik 2001: 197 f.). More specifically, I mobilized Buber's critique of reified I-It relationships and Levinas' warning against selfcentered attempts to take control of the Other as a critique of both spiritual and political self-sufficiency.

\section{Philosophies of necessary dialogue}

When returning to Buber and Levinas in my later book, written in 2006, entitled Islam og kristendom. Konflikt eller dialog? (Islam and Christianity. Conflict or dialogue?), Buber figures prominently in my use of 'the space between' as the book's pivotal metaphor, both for interreligious coexistence as a social phenomenon and interfaith dialogue as a spiritual practice. At this stage, I also employed the same metaphor to establish a critical research perspective, arguing the impossibility of stepping outside of the space between in order to take a neutral view of social relations in which everyone is already involved (Leirvik 2006: 113-19, 297-303).

I did not at this stage of my reflections compare Buber's philosophy of the between with contemporary social science-oriented notions, such as Homi Bhabha's 'Third Space', which adds valuable insight to the understanding of multicultural interaction. Quite similar to Buber's characterization of the realm between, Bhabha sees the third space from a communicative perspective, while maintaining that the production of cultural meaning always transcends the utterances of the I and the You. ${ }^{7}$ As Ruth Illman has also noted in her article for the present volume, Bhabha himself employs the notion of the 'in-between space' when unfolding his concept of the third space:

... it is the 'inter' - the cutting edge of translation and negotiation, the in-between space - that carries the burden of the meaning of culture. . . by exploring this Third Space, we may elude the politics of polarity and emerge as the others of our selves (Bhabha 2004: 56).

7 'The meaning of the utterance is quite literally neither the one nor the other' (Bhabha 2004: 56). 
Whereas Bhabha's approach is that of cultural analysis, Buber's meditations on the realm of the between in his book Between Man and Man (2002) gives a more philosophical contribution to the understanding of social relations and cultural meaning. Buber's philosophy borders on metaphysics, for instance when he speaks of dialogue as a third dimension beyond the individual and social aspects of existence:

In the most powerful moments of dialogic, where in truth 'deep calls unto deep', it becomes unmistakably clear that it is not the wand of the individual or of the social, but of a third which draws the circle round the happening. On the far side of the subjective, on this side of the objective, on the narrow ridge, where I and Thou meet, there is the realm of 'between. (Buber 2002: 242 f.)

Although Buber at this stage of my reflection process seemed to be more central to my reasoning than ever, in my book of 2006 I put equal emphasis on Levinas' explicit critique of Buber-particularly as spelled out in his essay on 'Dialogue' in Of God Who Comes to Mind (1998), where Levinas emphasizes the asymmetrical nature of human relationships. Suggesting that Buber understands the I-Thou relationship as 'a harmonious co-presence, as an eye to eye', Levinas states: 'There would be an inequality, a dissymmetry, in the Relation, contrary to the "reciprocity" upon which Buber insists, no doubt in error' (Levinas 1998: 150).

Correspondingly, in his critical dialogue with $\mathrm{Bu}-$ ber in Alterity and Transcendence, Levinas rhetorically asks: 'The other whom I address-is he not initially the one with whom I stand in the relationship one has with one who is weaker' (Levinas 1999: 100)? It is in this context that Levinas speaks also paradoxically about 'the distance of proximity' (p. 93). For him, the expression 'distance of proximity' epitomizes the understanding of 'dia-logue' as a form of communication which respects the asymmetry between me and the (almost divine) Other.

Ruth Illman notes that Buber, too, envisages some sort of dialectic between proximity and distance in human relationships. Even in a close relationship between I and Thou, there will be an element of I-It which maintains an analytical distance and the recognition of irreducible difference (Illman 2006: 26).

What then about the allegation that Buber in his interpersonal philosophy presupposes a reciprocity which in Levinas' view reduces the radicality of the ethical demand? In a defence of Buber against Levinas, Andrew Kelly notes that Buber does not exactly speak of reciprocity, but focuses instead on the kind of 'meeting' that characterizes any genuine I-Thou relationship. The central distinction here, Kelly argues, is that between 'reflecting' and 'addressing. Whereas reflection takes place in the I and is only related to It, an interpersonal relation presupposes that both I and You are allowed to be as he or she really is, in their otherness: 'It is in this way that speakingor addressing another-does nor destroy the height of the other' (Kelly 2004: 231). Something similar applies to the human being's relation to God, who (in His divine height) can only be addressed in His otherness, not in reciprocity.

For the purpose of this essay, I have been interested in finding out what Levinas' insistence on the asymmetry in any social relation (or Buber's notion of being addressed) resonated with in my experience of 'necessary dialogues' between Christians and Muslims in Norway. The first years of the ChristianMuslim Contact Group (from 1993 onwards) were marked by a form of communication in which the church representatives were addressed (Buber) by their Muslim partners from a moral height (Levinas) - by speaking from below, that is, from the perspective of a religious minority searching for recognition in a majority society still heavily influenced by the Christian cultural heritage-and increasingly by secular humanism.

From a more general perspective, it appears that Levinas' emphasis on asymmetrical relationships offered itself as an apt perspective on minority-majority relations in Norwegian society, in which the Church of Norway-by virtue of being a state church, and in spite of its emerging self-understanding as a faith community among others-is inevitably seen as an integral part of the majority society. In this sense, the initial distinction I made between dialogue initiatives originating from civil society actors and the state respectively, may be hard to draw in practice. For instance, critical research on interfaith dialogue between the faith communities has revealed the extent to which the agenda of such dialogues may reflect the discursive power of the majority representatives (Roald 2002). ${ }^{8}$

8 In an article about an interreligious dialogue group in Malmö, Sweden, Anne Sofie Roald demonstrates how much the agenda of this group reflected established social-ethical topics in Christian-ecumenical dialogue. She also notes a slight frustration among the Muslim participants that topics that were felt to be at 
In contrast, the multilateral Council for Religious and Life Stance Communities in Norway originated from the minorities' protest against the institution of a new compulsory subject of religious education in schools, which was announced in 1995, with a strong priority given to knowledge of Christianity as the country's dominant cultural heritage. As noted, the initial agenda of the Christian-Muslim Contact Group was much focused on Muslim minority concerns in Norway. However, what started out as minority Muslims addressing majority Christians (socially from below, but morally from above) gradually evolved into a form of interaction with clear elements of reciprocity (or mutuality). In my interpretation of Christian-Muslim dialogue in Norway, I have argued that active listening and sensitivity towards the situation of vulnerable minorities has gradually emerged as a common practice and shared concern. In this process, there is probably both Buberian reciprocity and Levinasian vulnerability and responsibility.

I am referring here not only to the work of the national Contact Group between the Church of Norway and the Islamic Council, but also to the work (from 1998 onwards) of the multilateral Oslo Coalition on Freedom of Religion and Belief ${ }^{9}$ in which Christian and Muslim leaders and human rights activists have played important roles in promoting religious freedom and interreligious dialogue with like-minded partners in other parts of the world.

As I have already explained, the early work of the Christian-Muslim Contact Group was marked by attentive listening on the part of the majority church to the minority concerns of Norwegian Muslims. For instance, for Christians it really took some active listening to understand Muslims' reservations about the new and compulsory subject of religious education in primary and lower secondary schools which (as mentioned) was felt to be too much dominated by a Christian majority interest by both Muslims, secular humanists and other religious minorities (a critique that was subscribed to by the European Court on Human Rights, in its verdict against Norway in 2007).

Naturally, this contentious issue became a central part of the Christian-Muslim Contact Group's agenda from the mid-nineties onwards. But at the same time, the Contact Group also engaged itself in the

odds with a liberal Christian agenda, such as heaven and hell or alcohol consumption, were never included in the group's agenda (Roald 2002).

9

http://www.oslocoalition.org/ precarious situation of Christian and other religious minorities in Muslim majority societies. The Contact Group's involvement in such affairs was first triggered by the fact that a couple of Norwegian imams supported the Pakistani death sentences in 1995 of three Christians who allegedly had violated the country's draconic blasphemy paragraph by insulting the Prophet.

There is quite a distance (maybe of proximity?) between the Islamic Council's reluctance to take a clear stand against the Pakistani blasphemy paragraph in 1995 and a joint Christian-Muslim statement issued in 2009 entitled 'Stop the violence against Christians in Pakistan' ${ }^{10}$ (mentally prepared by joint ChristianMuslim delegations to Pakistan in 2005-6). To cite another example, also in the case of the violent attacks against Coptic Christians around Christmas 2010-11, the Islamic Council was swift to announce their condemnation and solidarity. ${ }^{11}$

A possible interpretation of the processes in official Christian-Muslim dialogue in Norway is that the Contact Group has slowly but surely moved towards a joint concern for vulnerable minoritiesbe it Muslims in Norway or Christians in Pakistan or Egypt. Gradually, a shared concern seems also to have developed for vulnerable individuals whose integrity and well-being may sometimes be threatened by their own cultural and religious groups. In some recent statements of the Contact Group, about the right to conversion $(2007)^{12}$ and violence in close relationships (2009), ${ }^{13}$ the focus of attention has clearly moved from protection of minority groups to a defence of vulnerable individuals. To the extent that such statements are followed up in practice, one may here speak of interreligious dialogue as a form of practical solidarity (Illman 2006: 97).

\section{Dialogue and negotiation}

Levinas' focus on asymmetrical relationships, vulnerability and responsibility in dialogue offers itself as an obvious 'theory' of this kind of dialogical practice. But there is also an important element of reciprocity (or mutuality) in these processes which confirms Bu-

10 http://www.kirken. no/? event $=$ showNews $\&$ FamID $=93378$

11 http://irn.no/2006/index.php?option=com_content\&t ask=view\&id $=265$ \&Itemid $=39$

12 http://www.kirken. no/? event $=$ showNews $\&$ FamID $=101461$

13 http://www.kirken. no/ ?event $=$ showNews $\&$ FamID $=17453$ 
ber's view of the dynamics of genuine meeting and dialogue.

However, when Buber exemplifies reciprocity in dialogue, his most striking example has little to do with negotiated 'joint statements' between equal partners. In his essay on 'Dialogue' in Between Man and Man, Buber tells a story from Easter 1914 about a broken-off conversation between 'some men from different European peoples [who] had met in an undefined presentiment of the catastrophe, in order to make preparations for an attempt to establish a supranational authority' (Buber 2002: 6). Buber recalls that one of the Christian representatives considered that too many Jews had been nominated, to which Buber ('obstinate Jew that I am') responded by reminding the Christian that Jesus himself was a Jew. Then in the ensuing heated discussion something strange happens, apparently as a result of the eye-to-eye encounter between these two 'obstinate' men:

He stood up, I too stood, we looked into the heart of one another's eyes. "It is gone," he said, and before everyone we gave one another the kiss of brotherhood. The discussion between Jews and Christians had been transformed into a bond between the Christian and the Jew. In this transformation dialogue was fulfilled. Opinions were gone, in a bodily way the factual took place. (Buber 2002: 7.)

The quote illustrates well how far Buber is from an understanding of dialogue which is restricted to verbally based negotiations. In the cited examples from Christian-Muslim dialogue in Norway, there are clearly elements of negotiation, not least in the process towards joint statements on sensitive issues. But without the personal bonding that takes place over time in serious dialogue, negotiated statements may not be worth much.

Whereas Buber's vision of dialogue is almost mystical and oriented towards the personal bond, other philosophers of dialogue, such as Jürgen Habermas, seem not to make a clear distinction between dialogue and negotiation. The aim of communicative action in Habermas' sense is an exactly negotiated consensus. This is also how he understands the aim of dialogue among religious and secular citizens in his later writings. (Habermas 2005.) Other theorists of dialogue, however, are keen to distinguish between dialogue and negotiation. In the Norwegian context, Dag Hareide has made a sharp distinction not only between dialogue, debate and discussion, but also between dialogue and negotiation. Whereas negotiation aims at verbally expressed consensus or compromise, says Hareide, dialogue involves the whole person and does not necessarily have agreement as its aim (Hareide 2010).

In my own experiences of interreligious dialogue, there is something non-verbal and bodily in genuine dialogues, an element which resembles Buber's almost mystical experience in 1914 and indeed Levinas' conception of a 'distance of proximity' in which closeness does not at all presuppose agreement of opinion (verbalized or not). But as my examples from Christian-Muslim dialogue in Norway illustrate, on the basis of personal trust some sort of negotiation may also take place, in a joint effort to formulate a common stand in critical issues. If and when this happens, it could be for the sake of the vulnerable human being, whom in Levinas' sense should be seen as the invisible third party in the encounter between me and the other.

\section{Mutual change}

How then should the outcome of truly dialogical processes be interpreted? It is interesting to note that in many definitions of dialogue, or even of that which lies beyond dialogue, the notion of mutual change appears as a pivotal one. In 1982, John B. Cobb Jr (whose main horizon is Christian-Buddhist dialogue) published his book Beyond Dialogue. Toward a Mutual Transformation of Christianity and Buddhism (Cobb 1982). The starting point for Cobb's reflections is the radical difference between Christianity and Buddhism, which makes it impossible to claim that the two religions actually speak about the same things. Nevertheless, or exactly because of radical differences, Cobb implies, some kind of mutual transformation may take place in the space between the two religions - provided that Christians and Buddhists (literally) sit long enough together in attentive listening.

Whereas Cobb speaks of mutual transformation as something that takes place beyond (verbal) dialogue, the Norwegian dialogue activist and researcher Anne Hege Grung includes the notion of mutual transformation in her very definition of dialogue (or more precisely, of the potential outcome of dialogue):

One is not entering a dialogue with the aim of transforming the other(s), but to take part in the possible mutual transformation which 
might be the result of the encounter (Grung 2007: 290).

In this perception of dialogue, Levinasian insistence on radical otherness is not sufficient. According to Simone de Beauvoir, insistence on ontological otherness in interpersonal relationships may actually serve to seem to cement stereotyped cultural perceptions, for instance of essential differences between the sexes (Beauvoir 2000: 8, 757). Levinas' rather one-sided concentration on asymmetry and difference does also not seem to capture the dynamic that evolves when dialogic partners try to live up to the Habermasian ideal of a dominion-free communication (Habermas \& Kalleberg 1999: 205-11). From a Levinasian perspective, Habermas' communicative vision may always remain a (potentially misleading) ideal. It seems, however, that interreligious dialogue cannot live without this ideal. As expressed by Grung:

[t]he necessary respect required to start and to continue a dialogue is based on the principle that the partners in the dialogue are equalsequally controlling the themes, the presentation of themselves, the physical circumstances, and the aim of the effort (Grung 2007: 290).

However, it is exactly in the quest for a jointly controlled agenda that Levinasian insights into asymmetrical relationships are indispensable - in order to have an open and transparent communication about those discursive and political power relations that need to be transformed.

\section{The concept of change in dialogue didactics}

In my discussion so far, I have concentrated on institutionalized, representative dialogues. I have tried to illustrate how impulses from Buber, Levinas and Habermas have interacted in my (and other activistresearchers') quests for theoretical enlightenment with respect to actual practices in these dialogues.

In the Norwegian context, the question of theory and practice in dialogue has also arisen in connection with religious education in school. Having been involved in public debates about religious education and in continuing education of teachers in dialogue didactics, religion in school is part of the field of practice that has triggered my theoretical interest.

Since 1997, Norway is one out of relatively few countries in the world (Sweden and the United Kingdom are two other examples) that have introduced a joint subject of religious education in primary and lower secondary school (i.e. not only in upper secondary school, which is more common in other countries). As indicated above, the actual subject has been quite controversial as to its aims and contents, and the curriculum has been revised no less than four times in the course of eleven years. In this process, the name of the subject has also been changed from 'Christianity, Religion and Life stances' (KRL) to the more neutral 'Religion, Life stances and Ethics' (RLE).

Across these revisions, the aim of creating a common arena for ethical and interfaith dialogue in school remains a central one. The current curriculum speaks about 'dialogue between people with different views of questions related to faiths and life stances'. It aims also at 'dialogue adapted to different age stages' 14 but gives little help in understanding how these lofty aims could be translated into didactic practice. It seems also clear that actual teaching practices tend often to be oriented more towards intellectual knowledge than towards existential understanding.

As a contribution to the development of dialogue didactics, in 2003 the Faculty of Theology introduced a course with the heading 'Can dialogue be learnt?', ${ }^{15}$ which was later transformed into a regular master's course entitled the 'Philosophy of dialogue and dialogue didactics. In this course, the students read recent texts on interreligious dialogue, but also the modern classics of Buber, Levinas and Habermas. They also read Nordic and British pedagogues who have sought to translate philosophies of interreligious dialogue into classroom practice, as well as Paolo Freire's dialogical 'pedagogy of the oppressed'.

In Freire's understanding, 'dialogue' is the only form of communication which may free teacher and student from a mere 'commercial' transaction of knowledge-thus opening up a space for what Freire calls a 'liberating' pedagogy. This means also that for Freire, true dialogue aims at practice: 'To say the real word-which is work, which is practice-is to change the world' (Freire 2003: 62).

Here again, the notion of 'change' pops up in connection with philosophies of dialogue, in a conception where self-change can only meaningfully be seen in relation to 'change of the world'.

If one turns to some of the background documents on the school subject KRL/RLE, one will find

14 http://www.udir.no/grep/

Lareplan/?laereplanid $=707207$

15 http://folk.uio.no/leirvik/KDL.html 
that both Buber and Habermas (but not Levinas) are important points of reference (NOU 1995: 32). Among dialogical values, 'openness and plurality, freedom and tolerance' are cited as examples. Here too, the dynamic perspective of 'change' is mentioned as a characteristic aspect of dialogical communication-the outcome of which seems implicitly to be thought of as embracing a certain openness to values such as those cited above. In a reflection on 'Identity and Dialogue', which is also the title of this background document, it says: 'Whereas identity values emphasize continuity backwards, in relation to our own traditions, dialogue opens up for fresh thinking and change' (NOU 1995: 32). It is also emphasized, however, that change can never be enforced: 'The aim of dialogue is not forcing or alluring the other to change. That is the hallmark of propaganda. One takes part in dialogue so that all may learn, grow and change.' (NOU 1995: 32, my translation.)

The notion of change can also be found in the first teacher's guide for KRL that was produced in 1997. The teacher's guide notes that dialogue has often been seen as a method of gaining new insight. But if the attainment of new insight through dialogue is both possible and legitimate, the guide says, 'one must also be ready to accept that [dialogue] may lead to change-both in oneself and in the partner of conversation. Probably in view of possible apprehensions among the parents that religious education in school may actually lead to changes of religious identity, the teacher's guide adds: 'This [the possibility of change] applies particularly to ethical questions. ${ }^{16}$ Anyhow, a change (religiously or ethically) that may be wanted by some, could be seen as threatening by others (Leirvik 2001: 158).

In the context of the classroom, many pupils will not even have a clear religious identity, which implies that dialogue in the classroom (if it takes place at all) can actually be far more complex-and also more risky - than dialogues among formal representatives of well-defined faith communities. As the controversies around the subject illustrate, it was initially seen by the religious minorities as a majority-defined measure of social integration. If one adds the unequal power relation between teacher and pupil, the question of asymmetry becomes also more acute when

16 KUF (Ministry of Education and Research)/Nasjonalt læremiddelsenter: Veiledning til lærplanverket for den 10-årige grunnskolen (L97): Kristendomskunnskap med religions- og livssynsopploering, paragraph 3.4.2. talking about dialogue in the classroom. It seems thus that classroom dialogue cannot do without Levinas' critical comments on Buber, since responsible adults must always make sure that a certain 'distance of proximity' is maintained when engaging vulnerable young people in dialogues about religion and ethics.

\section{Conclusion}

My reflections have dealt with interreligious dialogue between pupils in the classroom, between believers in civil society, and between the state and the religious minorities. Each of these dialogues has their own characteristics and dynamics, and they call for different types of theorizing. But some questions recur across these different arenas of 'dialogue'. Even more than formal conversations between representatives of faith communities, the practice of classroom dialogue illustrates how complex and vulnerable interfaith dialogue may be, and how indispensable a critical power perspective is when reflecting about (mutual?) change as a possible outcome of dialogue.

The power question is probably most acute in state-initiated communication with the minorities. But it would be too simplistic to talk about interreligious dialogue in civil society as a dominion-free activity. Religious education in school illustrates in fact how difficult it is to draw a sharp line between state-initiated dialogues and those in civil society. On the one hand, religious education in a state school will reflect national ideologies and political priorities, either by giving space to confessional instruction or by opening up an arena for (state initiated) interreligious learning. On the other hand, the school can only contribute to creating good citizens if pupils are also allowed to communicate freely and critically, about religion and ethics. In the latter case, dialogue in the classroom may embody some of the same qualities as 'best practices' of civil society dialogues.

Oddbjørn Leirvik is Professor of Interreligious Studies at the Faculty of Theology, University of Oslo. His main fields of specialization are Islam and Christian-Muslim relations and interreligious dialogue. E-mail address: oddbjorn. leirvik@teologi.uio.no.

\section{References}

Amir-Moazami, Schirin, 2010. D'égal à égal? Herméneutique critique du dialogue initié par l'État avec les musulmans d'Allemagne. Sociologie et sociétés 42 (1): 171-96. 
Atterton, Peter, Matthew Calarco \& Maurice S. Friedman, 2004. Levinas \& Buber. Dialogue \& difference. Pittsburgh, PA: Duquesne University Press.

Beauvoir, Simone de, 200o. Det annet kjønn. Oslo: Bokklubben Dagens bøker.

Bhabha, Homi, 2004. The Location of Culture. London: Routledge.

Buber, Martin, 1987. I and Thou. Edinburgh: T\&T Clark.

-1988. Exclipse of God. Studies in the Relation between Religion and Philosophy. Atlantic Highlands, NJ: Humanities Press International.

-2002. Between Man and Man. With an introduction by Maurice Friedman. Translated by R. G. Smith. London \& New York: Routledge.

Cobb, John B., 1982. Beyond Dialogue. Toward a Mutual Transformation of Christianity and Buddhism. Philadelphia, PA: Fortress Press.

Freire, Paolo, 2003. De undertryktes pedagogikk. Oslo: De norske bokklubbene.

Grødum, Linda, 1999. Dialogue without Words. The Interaction of Giving and Receiving Massage. Mag. art. dissertation. Institute of Sociology, University of Oslo.

Grung, Anne Hege, 2007. Gender Perspective in MuslimChristian Dialogue: A Disturbance to Bridge-building or a Contextual Necessity? In: Mission to the World: Communicating the Gospel in the 21st Century. Essays in Honour of Knud Jørgensen. Oxford: Regnum Books.

Habermas, Jürgen, 2005. Religion in the public sphere. Holberg Prize lecture, Bergen 2005. Available also online: http://www.holbergprisen.no/images/ materiell/2005_symposium_habermas.pdf.

Habermas, Jürgen \& Ragnvald Kalleberg, 1999. Kraften $i$ de bedre argumenter. Oslo: Ad notam Gyldendal.

Hareide, Dag, 2010. Den fjerde samtaleformen. Morgenbladet 24.9.2010.
Heelas, Paul, 1996. The New Age Movement. The Celebration of the Self and the Sacralization of Modernity. Oxford: Blackwell.

Illman, Ruth, 2006. Ett annorlunda Du. Reflektioner kring religionsdialog. Göteborg \& Stockholm: Makadam.

Kelly, Andrew, 2004. Reciprocity and the Height of God. A Defense of Buber Against Levinas. In: P. Atterton, M. Calarco \& M. Friedman (eds), Levinas and Buber. Dialogue and Difference. 226-34. Pittsburgh, PA: Duquesne University Press.

Leirvik, Oddbjørn, 1990. Møte med islam. Oslo: Pax.

-1996. Religionsdialog på norsk. Oslo: Pax.

—2001. Religionsdialog på norsk. Ny og utvida utgåve. Oslo: Pax.

-2006. Islam og kristendom. Konflikt eller dialog? Oslo: Pax.

Lemke, Thomas, 2002. Foucault, Governmentality, and Critique. Rethinking Marxism 44 (3): 49-64.

Levinas, Emmanuel, 1993. Den annens humanisme. Oslo: Aschehoug.

-1998. Of God Who Comes to Mind. Trans. B. Bergo. Meridian: Crossing Aesthetics. Stanford, CA: Stanford University Press.

-1999. Alterity and Transcendence. Trans. M. B. Smith. New York: Columbia University Press.

NOU 1995. Identitet og dialog. Norges offentlige utredninger 1995:9. Oslo: Kirke-, Utdannings- og Forskningsdepartementet.

Roald, Anne Sofie, 2002. Religionsdialogiska perspektiv. En fallstudie av en dialoggrupp i södra Sverige. In: M. Stenmark \& D. Westerlund (eds), Polemik eller dialog? Nutida religionsteologiska perspektiv bland kristna och muslimer. Nora: Nya Doxa. 